\title{
aniki
}

Revista Portuguesa da Imagem em Movimento

Portuguese Journal of the Moving Image

\section{Olhar o céu, ouvir a terra: anotações sobre corpo, memória e paisagem no cinema de James Benning e Cao Guimarães Ana Costa Ribeiro ${ }^{1}$}

Se o cinema pode nos ajudar a enxergar o mundo, talvez seja porque os filmes podem criar diferentes perspectivas de revelar a realidade. Um filme nos atinge quando mudamos algo em nossa percepção depois de assisti-lo, como se tivéssemos feito uma travessia na qual sofremos modificações após o percurso. A fim de investigar de que formas o cinema pode nos atingir e transformar nossas percepções em determinado ambiente ou meio, este ensaio percorre algumas abordagens sobre o tema da paisagem.

Primeiramente, pesquisaremos a noção de paisagem segundo dois filósofos: Gilles A. Tiberghien e Anne Cauquelin. Ambos tratam da questão da paisagem como uma relação dos seres humanos entre si e com o ambiente ou meio. Em seguida, trataremos de investigar a noção de paisagem cinematográfica com a ajuda de um vocabulário apresentado pelos teóricos de cinema Arlindo Machado e Jacques Aumont.

A partir do esclarecimento de termos como "quadro," "campo" e "fora-de-campo," veremos como o cinema se desenvolve no tempo, num jogo de ritmo entre as imagens, dialogando com o pensamento da filósofa Marie-José Mondzain. Logo, com o auxílio dos pensadores Emmanuel Lévinas e Andreas Huyssen, refletiremos sobre uma das relações que é possível ter com as paisagens: sua relação com a memória.

Somente então poderemos seguir para a análise das propostas estéticas de alguns cineastas, que chamaremos de "poéticas do deslocamento," e que se configuram através de entrecruzamentos entre espaços e tempos dentro de um mesmo filme. Como exemplos dessas poéticas, trataremos de dois trabalhos: Ten Skies (2004), do artista norte-americano James Benning, e Sin Peso (2007), do artista brasileiro Cao Guimarães.

Poderemos, então, convocar os leitores/espectadores a construir o que chamaremos de "novas paisagens," isto é, novas formas de se relacionar com determinado ambiente ou meio a partir de espaços e tempos pelos quais percorremos. Por fim, pensaremos na questão da paisagem em sua relação com o corpo e com a memória, e

\footnotetext{
${ }^{1}$ Universidade do Estado do Rio de Janeiro, Instituto de Artes, PPGArtes - Programa de Pós-Graduação em Artes, Maracanã, 20550-010, Rio de Janeiro, Brasil.
} 
no modo como constrói novos ritmos de relação dos sujeitos com o mundo.

\section{Paisagem, enquadramento e composição}

Mesmo numa paisagem em que não se percebe a ação de um corpo, importa a relação que se configura. Nesse sentido, corpo, memória e paisagem são alguns elementos que podem se articular para pensarmos conceitualmente essas relações. Numa paisagem, corpos podem se relacionar entre si ou com o meio ambiente físico. Também podemos nos relacionar com uma paisagem através da memória de um indivíduo, de uma comunidade ou de um fenômeno físico. Desse modo, percebemos que a paisagem é uma relação que diz respeito tanto ao meio ambiente físico quanto à arte do enquadramento e da composição humanas.

Como indica o filósofo Gilles A. Tiberghien, "há uma dimensão da paisagem que é fundamental, a de que ela é uma relação, e não uma coisa, uma ligação entre os homens, e ao mesmo tempo o reflexo de sua atividade" $(2012,180)$. Tal afirmação sugere que a paisagem não é apenas um meio ambiente físico, e sim uma relação que o ser humano estabelece com determinado ambiente ou meio, uma forma de enquadrar a realidade, de lhe colocar molduras, de propor modos de convivência entre os seres e em sua relação com a natureza.

É preciso se pensar a questão da paisagem como um "ambiente ou meio que faça surgir um pensamento, um evento, uma relação" (Tiberghien 2012, 180). Ao pensar assim, não se aposta tudo nem nas paisagens, nem nas ações dos sujeitos, e se pode reconhecer que é justamente nessa fricção entre corpo e paisagem que a vida se dá.

Para a filósofa Anne Cauquelin, a noção de paisagem está relacionada tanto ao meio ambiente físico como à arte do enquadramento e da composição. Nesse sentido, a paisagem só existe em função de um enquadramento humano, ou seja, de uma seleção, de uma escolha, de um recorte de mundo, e ainda, de uma disposição dos elementos em jogo. "Contudo, se a moldura é necessária, ainda falta-nos indagar sobre sua composição. O que é que constitui a moldura - além do artifício exemplar da janela - para que a paisagem seja vista como tal?" (Cauquelin 2007, 139).

Segundo Cauquelin, a janela que se constrói visa manter o selvagem à distância, isto é, se configura como um aparato que nos permite domar a natureza. "Recordemos que Lucrécio já nos dizia que a natureza é para ser evitada, e nós podemos evitá-la, acrescentava ele: sim, porque temos a preciosa paisagem que, ao remeter à natureza, a domestica, interpondo entre ela e nós seu análogon civilizado" (Cauquelin 2007, 139). A moldura funcionaria, assim, como um dispositivo do olhar que restabelece uma distância. Para além da 
moldura, entretanto, haverá sempre uma extramoldura, isto é, algo que não se revela de imediato, mas que é elemento constitutivo da moldura, sua condição necessária. A forma como o artista dispõe os elementos dentro e fora da moldura lhe permite construir determinada composição no quadro da paisagem. À arte de escolher o que está dentro e o que está fora da moldura chamamos de enquadramento. Para construir determinada paisagem, é preciso que o artista tome uma série de decisões de enquadramento, domando assim a natureza. Questionar-se acerca do enquadramento e da composição é algo que permite uma reflexão mais profunda sobre as paisagens que aparecem no cinema.

Antes de avançar, portanto, seria interessante pensar na própria noção de quadro cinematográfico. O quadro cinematográfico equivale à moldura do quadro pictórico no sentido que se constitui pelas quatro bordas em jogo. $\mathrm{O}$ enquadramento, por sua vez, corresponde à arte de enquadrar, ou seja, de decidir o que colocar dentro do quadro.

Um filme é feito de planos, e cada plano é composto do enquadramento de determinado espaço durante um certo período de tempo, entre um corte e outro. O quadro do cinema moderno, em oposição ao quadro primitivo dos primeiros cinemas, costuma ter relação com o fora-de-campo, ou seja, com o espaço que fica fora do quadro.

O quadro primitivo, como indica o pesquisador Arlindo Machado, era um quadro autônomo, centrípeto, que buscava filmar o cinema como um "teatro filmado":

A câmera em geral não se movia; ela estava sempre fixa e a uma certa distância da cena, de modo a abraçá-la por inteiro, num recorte que hoje chamaríamos de 'plano geral'. (...) As entradas e as saídas dos atores eram laterais, como no teatro. Também como no teatro, era o deslocamento do ator para dentro ou para fora do cenário que compunha o quadro e não os movimentos de câmera, por enquanto, pouco significativos. A noção de montagem ainda não havia sido assimilada: mudava-se de cena apenas quando a ação seguinte deveria se passar num outro espaço ou num outro tempo. (1997, 92-93)

Já para o teórico de cinema Jacques Aumont, o quadro fílmico em si é centrífugo, enquanto o quadro pictórico é centrípeto: "O quadro fílmico, por si só, é centrífugo: ele leva o olhar para longe do centro, para além de suas bordas; ele pede, inelutavelmente o forade-campo, a ficcionalização do não-visto" $(2004,111)$.

Através da arte do enquadramento e da composição, o cinema se constitui como um espaço de reflexão privilegiado para se pensar a questão da paisagem. Se queremos pensar na paisagem como uma relação, é preciso pensar na paisagem cinematográfica também como uma relação, seja através dos gestos do cineasta, seja através dos gestos dos personagens ou atores sociais de determinado filme. Ao 
trabalhar com a arte do enquadramento e da composição, a paisagem cinematográfica se configura como uma inscrição de determinada paisagem através da escrita do artista. A paisagem cinematográfica é fruto de uma escrita que inscreve determinada paisagem no cinema.

Ao esclarecer determinados termos do vocabulário cinematográfico, Aumont nos apresenta algumas ferramentas de que o cinema dispõe para a construção dessas paisagens. Segundo o teórico, "o quadro é, antes de tudo, limite de um campo (...) Se o campo é a dimensão e a medida espaciais do enquadramento, o fora-de-campo é sua medida temporal e não apenas de maneira figurada: é no tempo que se manifestam os efeitos do fora-de-campo" (Aumont 2004, 40).

É nesse sentido que o cinema é um espaço privilegiado para se pensar na questão da paisagem, uma vez que trabalha sempre com a arte do enquadramento e da composição e, ainda, para além da tradição pictórica, acrescenta uma outra dimensão às inscrições das paisagens na arte: o tempo.

Nesse contexto, um dos traços distintivos do cinema na relação com o enquadramento é o fora-de-campo, uma vez que sua relação com o que está em campo só pode ser percebida através da passagem do tempo. O quadro cinematográfico supõe sempre um fora-de-campo, assim como a moldura supõe sempre uma extramoldura. Diferente da paisagem pictórica, a paisagem cinematográfica tende a ser construída através da relação constante entre campo e fora-de-campo, que se dá sucessivamente com o desenvolvimento do filme no tempo.

\section{Paisagem, imagem e memória}

“A imagem não está no espaço, ela tem a ver com o tempo. Diástole e sístole do presente e da ausência. A imagem se constitui na pulsação do real que nos captura e da vida que nos liberta. Ela é a aparição do ritmo" (Mondzain 1995, 15). Se a imagem é a aparição do ritmo, a imagem de uma paisagem talvez possa provocar uma dupla aparição do ritmo: o ritmo da imagem - que estabelece uma relação entre presença e ausência - e o ritmo da paisagem - que subentende uma relação entre o ser humano e determinado ambiente físico.

Segundo a filósofa Marie-José Mondzain, é a relação entre as realidades presentes e as realidades ausentes que situa as imagens no mundo:

L'image met en relation le présent de l'absence; plus encore, elle est ce qui nous met en présence de cette absence et qui la rend manifeste sous le signe de la relation. (...) Ces réalités absentes, l'image ne les convoque ni ne les évoque, elle les met au monde. Elle ne se laisse nullement remplir par une matière métaphorique ou analogique; bien au contraire, elle se retire de la forme même dans laquelle 
elle se montre, se laisse voir. Elle est un relatif, la figure de la relation $(1992,22)^{2}$

Se a imagem é um relativo, a imagem de uma paisagem também é a figura de uma relação. Desse modo, talvez a imagem de uma paisagem coloque em jogo duas versões de relação. Em primeiro lugar, a relação entre aquela paisagem física (a imagem natural) e a paisagem tal qual ela aparece na imagem (a imagem artificial); e, em segundo lugar, a relação entre a imagem natural e os corpos que se relacionam com ela.

As paisagens cinematográficas, portanto, permitem construções de diversas formas de ritmo, uma vez que lidam tanto com o ritmo da imagem quanto com o ritmo da paisagem, isto é, tanto com as relações entre a imagem natural e a imagem artificial, quanto com as relações entre as paisagens naturais e a percepção humana.

Alguns cineastas investem na construção de novos ritmos, que, por sua vez, criam a possibilidade de construção de novas configurações de enquadramento e composição das paisagens. Isso significa que, através de seus filmes, esses cineastas ampliam nossa percepção, fazendo com que também sejamos capazes de construir paisagens inéditas, desconhecidas até então, e, por sua vez, voltemos para o mundo com olhares renovados.

Dentre as inúmeras formas de ritmo que se pode estabelecer com as paisagens, destacamos a relação com a memória. No livro Paisagem e Memória, o escritor Simon Schama já indica uma relação intrínseca entre esses dois conceitos, ao estabelecer uma relação entre a natureza e a percepção humana. Para o escritor, tal relação é de tal forma imprescindível que, apesar de estarmos habituados a situálas em campos distintos, elas são inseparáveis. Para Schama, “Antes de poder ser um repouso para os sentidos, a paisagem é obra da mente. Compõe-se tanto de camadas de lembranças quanto de estratos de rochas" $(1995,17)$.

A fim de aprofundar a pesquisa sobre a relação entre paisagem e memória, seria interessante fazer uma reflexão acerca da noção de vestígio. Segundo o filósofo Emmanuel Lévinas, “o vestígio é a inserção do espaço no tempo" (Lévinas 2012, 65). Nesse sentido, o vestígio é a presença da ausência e a ausência, um estado que incorpora uma presença. Somente por meio do atravessamento da paisagem é possível deixar vestígios. Por isso, a conexão que temos com as paisagens passa por uma identificação dos vestígios. Ou seja,

\footnotetext{
${ }^{2}$ Uma possível tradução deste trecho para a língua portuguesa seria a seguinte: "A imagem coloca em relação o presente da ausência; ou melhor, ela é o que nos coloca na presença dessa ausência e a revela sob o signo da relação. (...) A imagem não convoca nem evoca essas realidades ausentes, ela as dá à luz. Ela não se deixa preencher em vão por uma matéria metafórica ou analógica; pelo contrário, ela se retira da mesma forma em que aparece, se dá a ver. Ela é um relativo, a figura de uma relação."
} 
nos relacionamos com determinada paisagem na medida em que reconhecemos que ela tenha sido atravessada por algo ou alguém, ou que apresente uma possibilidade de atravessamento.

O corpo que passa deixa um rastro na paisagem. São as marcas dessa passagem que inscrevem memória nos espaços. Na filosofia de Lévinas, "O vestígio não é um sinal como qualquer outro. (...) Ser, na modalidade de deixar um vestígio, é passar, partir, absolver-se (...)" (2012, 63-65). Além disso, o vestígio instaura um silêncio. Ele diz respeito tanto a uma alternância espacial (a presença de uma ausência) quanto a uma alternância temporal (o presente de um passado).

Nesse sentido, a relação entre paisagem e memória se faz através de negociações entre lembrança e esquecimento. O vestígio encontrado em determinada paisagem permite que algo seja lembrado - a passagem de um corpo, de uma comunidade, de um fenômeno físico, etc. - e, ao mesmo tempo, que algo seja esquecido, uma vez que o vestígio é a prova da existência de um passado no presente, isto é, de algo que já não está lá.

Desse modo, a coexistência da lembrança e do esquecimento é fundamental para se pensar na relação entre memória e paisagem. $\mathrm{O}$ vestígio é um índice de que algo se passou em determinado espaço. Desse modo, estabelece uma ponte entre espaço e tempo.

Para o pensador Andreas Huyssen, a memória não se dá somente no tempo: "A memória, é claro, não diz respeito apenas ao tempo, mas é sempre espacializada em contextos nacionais, urbanos e daí por diante. Então, tempo e espaço devem ser pensados juntos e eu não pensaria em separá-los, mas sim em vê-los em sua relação dialética" (cit. in Conde 2012). Ao analisar a obra do artista sulafricano William Kentridge, por exemplo, Huyssen afirma que:

A contínua metamorfose de coisas, rostos e paisagens é o princípio norteador da progressão do desenho. A rasura, o apagamento e a eliminação transformam-se nas manifestações materiais da própria estrutura da memória. O que resta do movimento do tempo é o vestígio $(2014,68)$.

O vestígio nos induz, portanto, a uma noção física da memória. Poderíamos então avançar para uma dupla abordagem da memória: a memória virtual e a memória física. Em oposição à memória virtual, a memória física se configura como uma memória inscrita numa superfície. Um filme, portanto, seria um exemplo de memória física. O cinema se dá sempre no tempo presente, mas em relação com algo que já não está lá, isto é, com um vestígio, com uma ausência. Nesse sentido, o cinema é ritmo - ritmo temporal e ritmo espacial. É preciso pensar o cinema através da dialética entre espaço e tempo. 


\section{Poéticas do deslocamento}

Atentos às possíveis coexistências de espaços e tempos distintos num filme, alguns cineastas exploram os entrecruzamentos entre essas dimensões, criando poéticas de deslocamento espaço-temporais que resultam em ritmos até então inexistentes. Uma das possibilidades de ritmo que pode ser construído através de paisagens cinematográficas é um ritmo em diálogo com a memória, isto é, a inscrição de determinada paisagem num filme pode se dar por meio da inscrição de distintas camadas de tempo, de deslocamentos entre passado, presente e futuro.

Acerca da relação entre cinema, memória e paisagem, é importante pensar não só na questão de um atravessamento da paisagem, como também na de um alinhamento da memória. Isto é, alternando-se espaços e tempos, entrecruzando paisagens e memórias, a escrita cinematográfica permite que o artista crie novos ritmos, através de poéticas do deslocamento que situam o espectador em espaços e tempos até então desconhecidos. É a criação de novos ritmos que permite a criação de novas formas de se perceber o mundo, de novas formas de enquadramento e composição da realidade, de novas formas de propor relações entre os elementos que estão em jogo.

$\mathrm{Na}$ arte contemporânea em geral e, particularmente, na criação audiovisual contemporânea, há uma aproximação das paisagens através da organização de vestígios, sejam eles encontrados naturalmente nas paisagens, sejam eles produzidos especialmente para elas. Reconhecer que as paisagens tenham sido percorridas por outros corpos que ali deixaram vestígios ou produzir artificialmente vestígios para se deixar nas paisagens é algo que permite a criação de novos enquadramentos e composições.

Tendo em vista as reflexões sobre cinema, memória e paisagem, podemos analisar dois filmes: o longa-metragem Ten Skies (2004), do artista norte-americano James Benning, e o curtametragem Sin Peso (2007), do artista brasileiro Cao Guimarães. Nesses trabalhos, tanto Benning quanto Guimarães constroem deslocamentos entre diferentes espaços e tempos, criando assim poéticas que se dão num eixo vertical - seja ao olhar o céu, seja ao ouvir a terra, os artistas propõem formas diferenciadas de percepção das paisagens e, desse modo, ampliam as possibilidades de relação que podemos estabelecer com elas.

Na longa-metragem Ten Skies ${ }^{3}$ (2004), James Benning usa enquadramentos fixos em longos planos, de aproximadamente dez minutos cada, utilizando um rolo de $120 \mathrm{~m}$ de película $16 \mathrm{~mm}$ para cada tomada. $\mathrm{O}$ filme consiste em dez planos que apontam para céus

\footnotetext{
${ }^{3} \mathrm{O}$ filme pode ser assistido no link: https://www.youtube.com/watch?v=dnBGr6VsDVU. Acesso em: 03 de novembro de 2016.
} 
com características muito distintas, todos filmados em Val Verde, na Califórnia. Como em seu filme anterior, 13 Lakes $^{4}$ (2004), em Ten Skies há uma relação de deslocamento entre um plano e outro, o que se observa devido às mudanças da paisagem - som, luz, vento, cor, movimento das nuvens, etc. - que são anunciadas por microintervalos de tela preta que separam os céus. Mas há também relações internas dentro de cada plano. No caso de Ten Skies, essas relações são mais perceptíveis através do som.

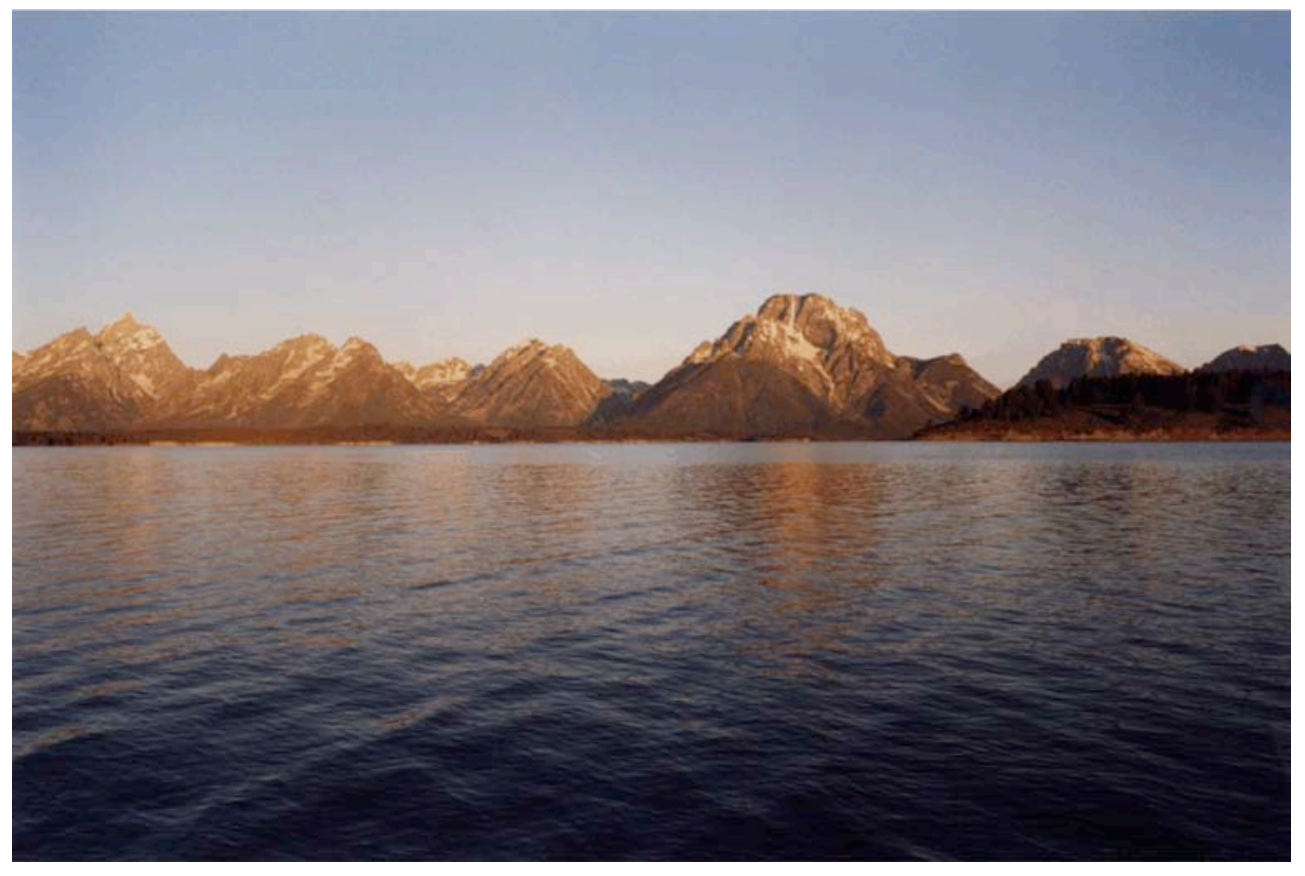

Imagem 1: 13 Lakes (James Benning, 2004)

Diferente de seu filme anterior, 13 Lakes, entretanto, no qual relações de deslocamento se dão na horizontal por meio de uma cartografia do país que segue a localização de seus lagos, Ten Skies apresenta relações de deslocamento que se dão num eixo vertical. Através dos diversos sons que se ouve ao longo do filme, sugere-se relações entre cada céu e cada terra que está abaixo dele. Imagina-se, então, uma paisagem urbana, uma paisagem industrial, uma paisagem rural, etc. Há duas estratégias de registro no filme, que nos ajudam a identificar uma paisagem possível para cada plano: registros visuais no céu (mudança de clima, nuvens que se deslocam, a noite chegando, a passagem de um helicóptero, o voo de gaivotas, etc) e registros sonoros na terra (indústrias, carros, motores de barco, trechos de conversas, latidos de cachorros, etc).

\footnotetext{
${ }^{4}$ Um trecho do filme pode ser assistido no link: https://www.youtube.com/watch?v=TKwhBk4d7M0. Acesso em: 03 de novembro de 2016.
} 
Ao apontar a câmera para o céu, o artista cria um gesto cinematográfico que possibilita um novo enquadramento da paisagem. Assim, os espectadores ficam de tal modo atentos ao que acontece com o som que podem imaginar a cena que se passa abaixo de cada céu, na terra. É o nosso envolvimento com a faixa sonora que nos permite criar uma paisagem possível para aqueles céus. É claro que cada espectador imaginará uma paisagem distinta. Mas é esse engajamento em identificar o que se passa que faz com que criemos uma relação com a paisagem implícita.

Para um conhecimento mais profundo sobre as estratégias poéticas do filme, vejamos o que acontece em cada plano:

$1^{\circ}$ Céu: Vemos um rastro de nuvem no céu. O som é uma mistura de ruído urbano com ruído de natureza. Ouvimos alguns cantos de pássaros misturados com burburinho de trânsito da cidade. Imaginamos uma paisagem composta por tons de cinza e verde. Talvez haja uma coruja. O céu parece escurecer para um azul mais intenso, mas isso pode ser apenas uma impressão. O rastro de nuvem, quase imperceptivelmente, vai se dissolvendo para as bordas do quadro. $\mathrm{O}$ azul mais intenso invade o quadro. Os pássaros cantam mais alto. Anoitece.

$2^{\mathbf{o}}$ Céu: Parece que ouvimos o som do motor de um barco. Vemos nuvens carregadas com as bordas brancas e o centro cinza. No horizonte distante, uma gaivota cruza o quadro. Há uma luz no fundo que indica o caminho do sol. Outra gaivota cruza o quadro da esquerda para a direita. Percebemos que o ruído do barco pode ser também o ruído de um helicóptero. Talvez as gaivotas estejam se afastando do helicóptero. As nuvens começam a invadir o quadro, cada vez mais espalhadas. Há apenas dois pequenos pontos de azul na superfície do quadro. Finalmente, as nuvens escurecem e preenchem todo o quadro. É um helicóptero. O tempo fecha.

$3^{\circ}$ Céu: As nuvens estão brancas e cinzentas e ouvimos um ruído de natureza. Parece uma paisagem no campo. Mas agora ouvimos um carro passando. Talvez seja uma estrada que percorre um longo trajeto, atravessando uma zona rural. Um dos pássaros tem o canto mais intenso que os outros. As nuvens vão se tornando mais claras. Deslocam-se sempre da direita para a esquerda, o que indica que o vento está vindo do espaço fora-de-campo do lado direito do quadro. Às vezes, um pássaro cruza o quadro quase imperceptivelmente. Uma moto atravessa a paisagem. Depois da chuva. Talvez seja um arco-íris. O tempo abre.

$4^{\circ}$ Céu: Céu azul anil. Nuvens brancas e fofas. Um dia claro. Estamos num pequeno vilarejo. Talvez haja um rádio transmitindo uma partida de futebol. Um homem canta: no puedo más... Homens mexicanos trabalham. E dizem entre si que: no pueden más... No rádio agora toca uma música. Talvez haja abelhas. Muitos pássaros e o ruído do empilhamento de caixas. O motor de uma caminhonete se 
aproxima. O motorista estaciona o veículo perto do trabalho dos homens. As caixas são colocadas na caminhonete. Há uma máquina funcionando à distância. As abelhas estão mais intensas. Um homem grita para o outro. A caminhonete sai. Um homem canta e dá uma gargalhada. A voz de uma mulher. É o fim do dia.

$5^{\circ}$ Céu: Uma paisagem na natureza. Supomos que há presença de água. O sol está parecendo a lua cheia. O som de um motor de barco ou de um helicóptero. As nuvens se espalham em forma de carneirinhos e depois de algum tempo a mancha de luz se dissolve e podemos perceber a bola do sol por trás das nuvens. Os animais podem ser patos, ou outros que frequentem a beira de um lago. Um cachorro late, anunciando a chegada da noite. Há diversidade na fauna. Uma coruja. O motor ao longe. O helicóptero cruza o quadro. Um sapo-martelo. O cão late. Anoitece novamente.
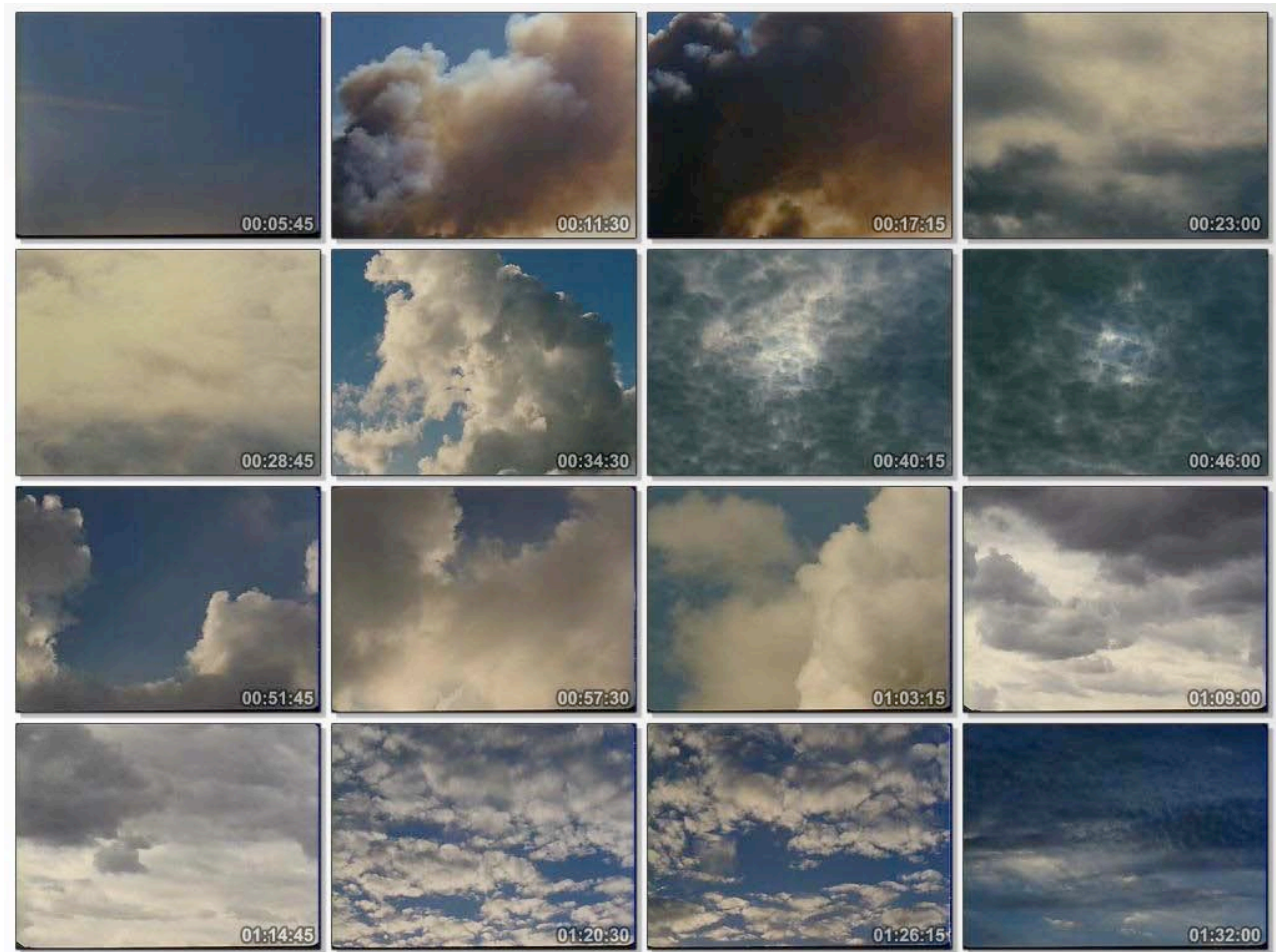

Imagem 2: Ten Skies (James Benning, 2004)

$6^{\circ}$ Céu: O céu está azul claro e as nuvens se movimentam relativamente rápido. Aviões, barcos a motor. Talvez estejamos sobre uma paisagem com água. Parece que um avião cruzou o céu, mas talvez seja o rastro de uma nuvem. As nuvens agora se movimentam mais devagar. O som do movimento da água talvez seja de uma pequena onda quebrando na beira do lago. As nuvens não são mais brancas. A massa cinza invade o quadro. Os ruídos silenciam. Um trovão. Vai chover. O tempo fecha novamente. 
$7^{\mathbf{0}}$ Céu: Parece que estamos numa paisagem industrial, mas não há tons de cinza. Há nuvens no céu e em primeiro plano vemos uma fumaça branca subindo com força. Ouvimos o som de diversas máquinas. O vento está soprando da esquerda para a direita, pois a fumaça desliza para o canto direito do quadro. $O$ fato de a fumaça não ser escura nos faz questionar se ela vem mesmo de uma fábrica. Às vezes ouvimos um pássaro. Som de motor. O vento está intenso. A fumaça continua. $O$ dia segue.

$8^{\circ}$ Céu: O céu está cinza. Ouvimos uns estalos à distância. Talvez alguém esteja caçando. Diversos sons ecoam no céu: avião, latidos de cachorro, cantos de pássaros. O avião se aproxima. Estalos, estalos. Cães latindo. O barulho dos estalos incomoda os cachorros. Vozes de pessoas à distância. Gritos, gargalhadas. Há uma comunidade. Talvez os estalos não sejam tiros de caça. Talvez sejam tiros ao alvo. O motor de um carro. Quando os estalos diminuem, os cachorros mudam a forma de latir. Os sons de pessoas lembram o burburinho de uma escola. O cinza que tomava o céu vai se dissipando e as nuvens clareiam um pouco. O tempo abre novamente.

$9^{\circ}$ Céu: As nuvens parecem pequenos carneiros espalhados no céu. Som de um alto-falante. Motor, buzina. Burburinho de um restaurante. Uma paisagem urbana. Diferentes intensidades de sons de motor: mais graves, mais agudos. A voz de uma mulher. Pessoas conversam em inglês. Risos. Carros passando. Uma moto. Uma máquina é ligada. Vozes de homens. Um carro acelera. Uma comunidade que vive na beira de uma estrada. Talvez seja a saída de um supermercado em uma grande avenida. O som de carros é constante. Uma buzina. As nuvens agora têm outra forma. Agora parecem ovelhas. Um martelo batendo. Alguém conserta alguma coisa. As vozes mudam, o que indica que as pessoas estão em trânsito. Há um fluxo de pessoas. A vida segue.

$\mathbf{1 0}^{\circ}$ Céu: Apenas natureza. As cigarras cantam. Nuvens cor de chumbo. O som de um avião ecoa no céu. Uma gaivota cruza o quadro. A buzina de um barco. Parece que estamos sobre a paisagem de um lago. O motor se aproxima. A parte debaixo do quadro está azul. É nela que vemos o rastro de um avião que cruza o quadro e deixa um vestígio branco no céu. O rastro se perde no horizonte como se fosse um cometa. Com ele leva o dia e nós, espectadores, vamos aos poucos deixando o filme. As cigarras cantam. O som de outros animais se torna mais intenso. Um motor à distância. O céu escurece. A noite cai. Vozes. É o fim do filme.

As experiências de assistir à projeção de Ten Skies e à do curta-metragem Sin Peso (Cao Guimarães, 2007) ${ }^{5}$ apresentam algumas semelhanças. Os dois filmes propõem uma poética do deslocamento

\footnotetext{
${ }^{5}$ Um trecho do filme pode ser assistido no link: http://www.caoguimaraes.com/obra/sin-peso/. Acesso em: 03 de novembro de 2016.
} 
que se dá através de um eixo vertical. Isto é, há um entrecruzamento de espaços e tempos que acontece, sobretudo, através da relação entre a imagem que vemos ao olhar cada céu e o som que ouvimos ao escutar cada terra.

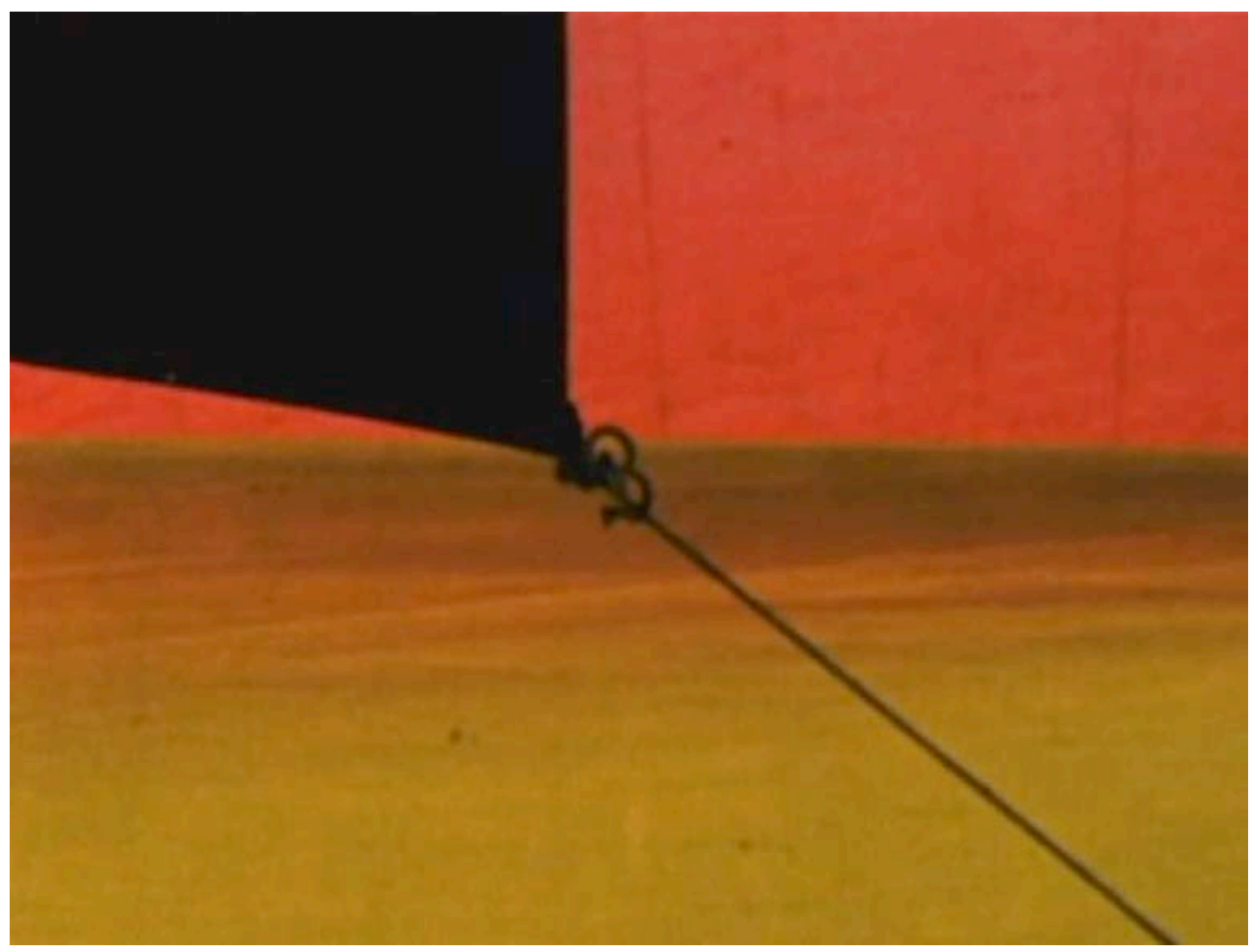

Imagem 3: Sin Peso (Cao Guimarães, 2007)

Sin Peso se passa no México, e é composto por vozes de vendedores ambulantes e imagens de toldos coloridos. $\mathrm{O}$ gesto cinematográfico de Cao Guimarães consiste em olhar e ouvir a paisagem ao mesmo tempo que se deixa olhar e ouvir por ela. Segundo a poética das asas do filósofo Gastón Bachelard, o corpo do pássaro é feito do ar que o cerca. Poderíamos dizer então que os corpos são feitos das paisagens que os cercam. Alternando-se as paisagens, somos capazes de redesenhar a forma como os corpos ocupam os espaços. Como sugere o verso de William Blake, citado por Bachelard: "O pássaro do mar toma a rajada de inverno como roupa para o seu corpo" (2001, 78).

Neste curta-metragem, há um duplo deslocamento no modo em que o artista apreende a paisagem. No eixo horizontal, as cores das lonas mudam, o que indica que a câmera passa por diferentes locais. No eixo vertical, as vozes dos vendedores ambulantes ecoam através de um desenho de som contínuo, que transpassa os cortes de imagem. Um trabalho como esse amplia as possibilidades de relação numa paisagem, e coloca em questão as diferentes dimensões que compõem um espaço. 
Na sinopse do filme, somos informados de que "o ar que sai do peito em vozes multiformes no comércio das ruas não é o mesmo ar que balança os toldos multicoloridos que protegem do sol e da chuva os donos das mesmas vozes" (Guimarães, 2007). Isso sugere que as vozes que ouvimos na terra não foram gravadas necessariamente no mesmo momento em que cada toldo foi filmado contra o céu. Há um trabalho de montagem que expande nossa percepção da paisagem através de entrecruzamentos espaço-temporais. Ao posicionar o espectador em tal situação, Cao Guimarães cria uma possibilidade de deslocamento sem fazer um único movimento de câmera. Desse modo, percorremos as ruas da Cidade do México sem sair do lugar. $\mathrm{O}$ artista cria assim uma teia de vozes e cores.

Num curta-metragem realizado no ano anterior, Quarta-feira de cinzas $(2006)^{6}$, Cao Guimarães constrói outra espécie de trama através da organização de vestígios - os vestígios de um carnaval -, na medida em que filma formigas carregando confetes. Nesse trabalho, o vestígio também aparece através de uma singela faixa sonora: um samba tocado numa caixa de fósforos. Seguindo o pensamento de Emannuel Lévinas, o artista guarda nessa obra o silêncio de um carnaval que passou. Ao se deslocar em quadro, as formigas vão transformando as paisagens por meio de um reposicionamento dos vestígios. Do mesmo modo, o deslocamento de um samba de carnaval para uma caixa de fósforos reconfigura os vestígios da sonoridade da festa. Dessa forma, o artista inscreve uma nova percepção da paisagem no cinema através de sua escrita.

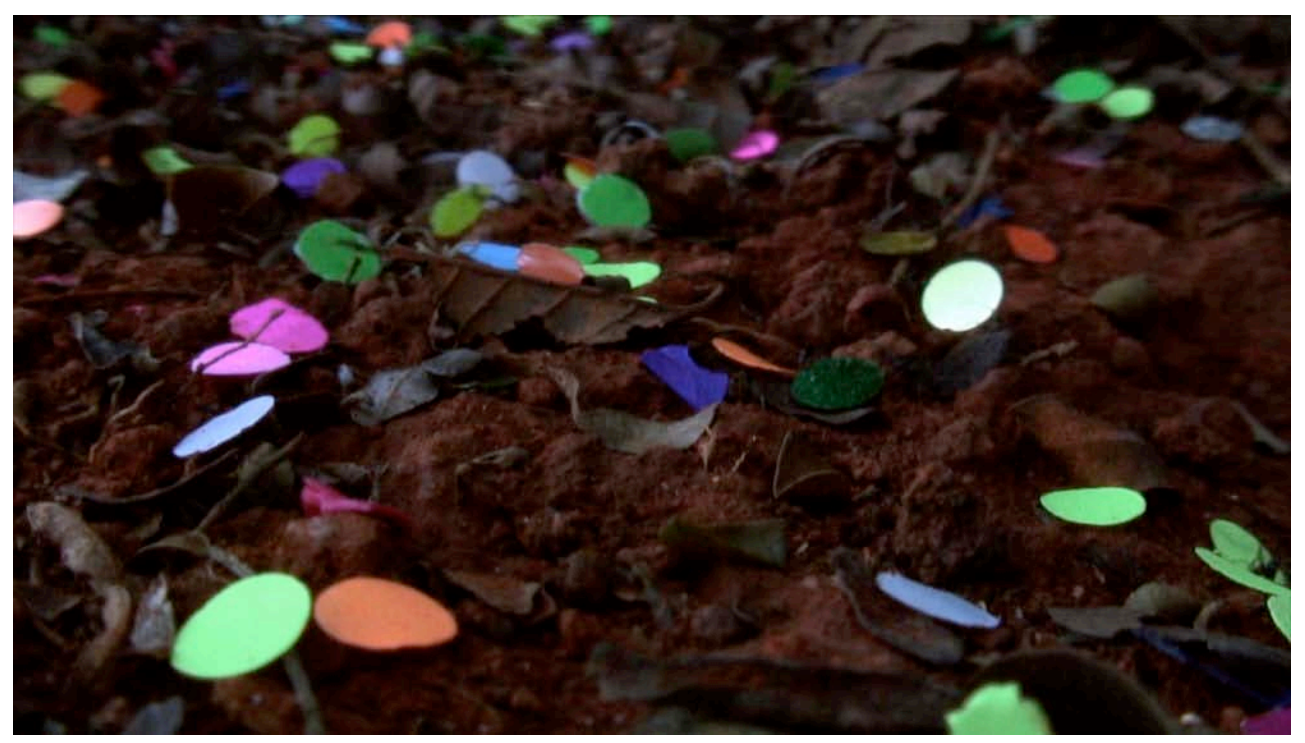

Imagem 4: Quarta-feira de cinzas (Cao Guimarães, 2006)

\footnotetext{
${ }^{6} \mathrm{Um}$ trecho do filme pode ser assistido no link: http://www.caoguimaraes.com/obra/quarta-feira-de-cinzas. Acesso em: 03 de novembro de 2016.
} 


\section{A escrita como construção de novas paisagens}

Neste momento, torna-se importante refletir sobre a própria noção de escrita como vestígio. Para falar sobre a escrita em si, a filósofa Jeanne Marie Gagnebin recorre a Aleida Assman:

Aleida Assman se detém ainda numa outra metáfora-fundadora de nossa concepção de memória e de lembrança: a da escrita, este rastro privilegiado que os homens deixam de si mesmos, desde as estelas funerárias até os e-mails efêmeros que apagamos depois do uso - sem esquecer, naturalmente, os papiros, os palimpsestos, a tábua de cera de Aristóteles, o bloco mágico de Freud, os livros e as bibliotecas: metáforas-chave das tentativas filosóficas, literárias e psicológicas de descrever os mecanismos da memória e do lembrar. Embora sempre tivesse havido uma outra imagem para dizer esses mecanismos, a imagem da imagem justamente, parece que até hoje, e apesar da tão comentada preponderância contemporânea das imagens sobre o texto, continuamos falando de escrita, escritura, inscrição quando tentamos pensar em memória e lembrança. (Gagnebin, 2006, 111)

Se a escrita é um rastro, um vestígio que insere o espaço no tempo, então organizar os fragmentos da memória em função de uma escrita não implicaria editar as paisagens em que vivemos, a fim de avançar rumo a novas paisagens? Isto é, se podemos escolher as paisagens que queremos guardar em nossa memória e de que forma queremos dispô-las em nossas narrativas, será que podemos criar novas formas de se perceber o mundo e, desse modo, propor novas formas de convivência entre os seres? Ou seja, a fim de avançar rumo a novas configurações do mundo, não seria necessário inscrever nossa memória, deixar rastros, vestígios nas paisagens pelas quais percorremos?

Uma forma de se avançar rumo a novas paisagens, portanto, será estabelecer cruzamentos entre memória e paisagem, tanto no sentido de um atravessamento espacial quanto no sentido de um alinhamento temporal. Esse cruzamento, entretanto, será sempre uma negociação entre escrita e apagamento, memória e esquecimento, fluxo e corte.

Como nos ensina Andreas Huyssen ao analisar a obra de William Kentridge:

O binário corriqueiro memória versus esquecimento, como uma escolha tipo ou isto, ou aquilo, é desmentido pela preservação de vestígios do passado, sob a forma de sombras, manchas e contornos mnêmicos nos desenhos, e até dos vestígios de pó de carvão visíveis no papel e no filme. Ainda que apenas sugerido em elementos vestigiais, o passado permanece materialmente presente em resíduos parecidos com sombras. As diferentes formas de esquecimento são parte da memória, inescapavelmente. Lembrar significa ler vestígios; requer imaginação, atenção do olhar, construção. $(2014,68)$ 
Ora, se lembrar significa ler vestígios, a memória de uma paisagem está diretamente relacionada com o que se deixou ou se encontrou nela.

Nesse contexto, vale lembrar particularmente o que se entende por percurso, na medida em que a transformação das marcas da memória num devir subentende uma trajetória. Da noção de percurso, chega-se à imagem da estrada, do caminho, da trilha. A etimologia da palavra francesa "route" (estrada, caminho, trilha) aponta para a palavra latina "rupta" (via aberta à força), particípio passado de "rumpere," que significa "romper." O que propomos, portanto, é que nos deixemos contaminar pela memória das paisagens, justamente para que possamos romper com elas. Através da identificação de vestígios ao longo do percurso é possível se construir novas paisagens e, desse modo, novos devires.

Tais deslocamentos entre as paisagens que já conhecemos e novas paisagens que podemos construir a partir de nossa experiência ecoam com uma proposta do filósofo Jacques Rancière. Para ele, o que importa é a ação do sujeito na cena. Rancière defende que é a partir da reinvenção da realidade, que dispõe os corpos pelos lugares, que se pode transformar o mundo:

Mas também essas histórias de espaços e de trajetos, de caminhantes e de viagens, podem ajudar a inverter a perspectiva, a imaginar não as formas de uma arte posta adequadamente a serviço de fins políticos, mas formas políticas reinventadas a partir das múltiplas maneiras como as artes do visível inventam olhares, dispõem corpos pelos lugares e os fazem transformar os espaços que percorrem. (2012, 145).

O que se nota, portanto, é que há uma dinâmica na relação entre corpo, memória e paisagem que é de tal maneira fundamental para o acontecimento humano que deve ser reativada sempre. O problema é que, historicamente, o ser humano se acostumou a polarizar esses dois modos de se situar no mundo. Estamos constantemente em conflito entre seguir (fluxo) ou romper (corte) com as paisagens em que vivemos. Como se não houvesse a possibilidade de negociação entre corpo, memória e paisagem.

Entretanto, percebe-se que o ser humano necessita desses dois movimentos que, aparentemente, parecem opostos. Caminhar e parar, viajar e não-viajar, seguir o fluxo e fixar-se em construções. Mas então o que está em jogo? O que sucede é a necessidade de um deslocamento na própria maneira de se pensar as relações que podemos estabelecer com as paisagens. Talvez o problema seja uma ênfase na separação entre espaço e tempo, como se as paisagens fossem apenas cenários nos quais os corpos se movem.

Como foi sugerido, as poéticas do deslocamento no cinema entrecruzamentos espaciais e temporais dentro de um mesmo filme - permitem uma expansão acerca do pensamento sobre a paisagem 
através de suas relações com o corpo e com a memória. Sobre as relações entre paisagem e cinema, é importante ressaltar a potência do som e de sua associação com o corpo e com a memória na construção de novas paisagens. Assim, para se mergulhar num conhecimento sensível das paisagens, deve-se levar em consideração as paisagens sonoras: sua atmosfera, seu ritmo, sua vibração.

\section{BIBLIOGRAFIA}

Aumont, Jacques. 2004. O olho interminável [cinema e pintura]. São Paulo: Cosac \& Naify.

Bachelard, Gaston. 2001. O Ar e os Sonhos. São Paulo: Martins Fontes.

Cauquelin, Anne. 2007. A Invenção da Paisagem. São Paulo: Martins Fontes.

Conde, Miguel. 2012. "Andreas Huyssen discute relações entre políticas da memória e direito”. Globo Universidade, 3 de agosto. Acesso em 31 de junho de 2016. Disponível em: http://redeglobo.globo.com/globouniversidade/noticia/2012 /08/andreas-huyssen-discute-relacoes-entre-politicas-damemoria-e-direitos.html

Gagnebin, Jeanne Marie. 2014. Lembrar, escrever, esquecer. São Paulo: Editora 34.

Guimarães, Cao. Sem data. "Sin Peso (2007)" [sinopse]. Acesso em 30 de junho de 2016. Disponível em: http://www.caoguimaraes.com/obra/sin-peso/

Huyssen, Andreas. 2014. Culturas do Passado Presente. Rio de Janeiro: Contraponto Editora.

Lévinas, Emmanuel. 2012. Humanismo do outro homem. Petrópolis: Editora Vozes.

Machado, Arlindo. 1997. Pré-Cinemas \& Pós-Cinemas. Campinas: Papirus Editora.

Rancière, Jacques. 2012. As Distâncias do Cinema. Rio de Janeiro: Contraponto Editora.

Schama, Simon. 1995. Paisagem e Memória. São Paulo: Editora Schwarcz.

Tiberghien, Gilles. 2012. "Trajetória e interesses: entrevista com Gilles A. Tiberghien”. Revista-Valise v.2, n. 3, ano 2 (julho): 177185. 
169 | ANA COSTA RIBEIRO

\section{FILMOGRAFIA}

Ten Skies [longa-metragem] Dir. James Benning. EUA, 2004. 109 min.

13 Lakes [longa-metragem] Dir. James Benning. EUA, 2004. 133 min.

Sin Peso [curta-metragem] Dir. Cao Guimarães. Brasil, 2007. 7 min.

Quarta-feira de cinzas [curta-metragem] Cao Guimarães, 2006. 5:44 min.

Recebido em 30-06-2016. Aceite para publicação em 21-11-2016. 